\title{
PENENTUAN NILAI SPF (SUN PROTECTING FACTOR) EKSTRAK ETANOL JAMUR KANCING (Agaricus bisporus) SECARA IN VITRO DENGAN METODE SPEKTROFOTOMETRI UV-VIS
}

\author{
Asriani Suhaenah, Masdiana Tahir, Nasra \\ Fakultas Farmasi, Universitas Muslim Indonesia, Makassar \\ Email: asriani.suhaenah@umi.ac.id
}

\begin{abstract}
Chronic exposure to ultraviolet light from the sun will cause changes in skin structure and oxidative stress on the skin. The effects can be in the form of acute changes such as erythema, pigmentation and photosensitivity, as well as long-term effects of premature aging and skin damage. Sun Protection Factor (SPF) is a universal indicator that explains the effectiveness of a product or substance that is UV protection. Natural ingredients that can be used as UV protection are button mushrooms (Agaricus bisporus). This study aims to determine UV light protection activity in the ethanol extract of button mushrooms (Agaricus bisporus) based on the SPF values analyzed by UV$V i s$ spectrophotometry at wavelengths of 290-320 nm. The results showed that at concentrations of $1 \%$ and $2 \%$ had a medium SPF category with SPF values of 17,762 and 28,643. For concentrations of $3 \%$ and $4 \%$ it has a high SPF category with SPF values of 30,592 and 31,325. The higher the concentration used, the better the SPF value.
\end{abstract}

Key words: SPF value, Agaricus bisporus, UV-VIS, Spectrophotometry.

\section{PENDAHULUAN}

Kulit merupakan organ terbesar dari tubuh yang memiliki peran sebagai sebagai pelindung antara tubuh bagian dalam dan bagian luar. Beberapa fungsi kulit yang lain adalah berperan sebagai pengaturan suhu tubuh, keratinisasi, pembentukan vitamin $D$, pembentukan pigmen, absorpsi, ekskresi, dan persepsi. $^{5}$

"Matahari adalah sumber kehidupan" . Hal ini didasarkan karena segala tahapan proses kehidupan yang terjadi memerlukan sinar matahari. Proses pembentukan vitamin D, warna kulit yang terjadi pada kulit manusia juga sangat membutuhkan bantuan sinar matahari. Namun, selain efek tersebut, matahari juga dapat memberikan efek yang berbahaya karena paparan dari sinar yang dimilikinya.

Pemaparan sinar ultraviolet dari matahari secara kronik akan mengakibatkan perubahan struktur kulit dan stress oksidatif pada kulit. $^{2}$ Efek yang ditimbulkan dapat berupa perubahan-perubahan akut seperti eritema, pigmentasi dan fotosensitivitas, maupun efek jangka panjang berupa penuaan dini dan kerusakan kulit. ${ }^{12}$

Antioksidan merupakan senyawa yang memiliki beberapa peran dalam kesehatan seperti dapat menunda, memperlambat, dan mencegah terjadinya reaksi oksidasi radikal bebas dalam oksidasi lipid. ${ }^{5}$ Peranan lain yang dimiliki oleh antioksidan adalah dapat mengatasi implikasi reaksi oksidasi dalam tubuh yang dapat menyebabkan penyakit kardiovaskuler, kanker, dan penuaan. ${ }^{9}$

Paparan dari sinar UV dapat memberikan pengaruh buruk pada kulit karena dapat menyebabkab kulit rusak sehingga mengganggu kesehatan dan penampilan dari seseorang. Oleh karena itu sangat dianjurkan untuk menggunakan tabir surya (sunscreen) 
Penentuan nilai SPF (Sun Protecting Factor) ekstrak etanol jamur kancing (Agaricus bisporus) secara in vitro dengan metode spektrofotometri UV-VIS

karena dapat mencegah atau meminimalkan efek dari sinar UV yang berbahaya terhadap kulit, serta menggunakan bahan-bahan yang memiliki efek perlindungan terhadap sinar UV. ${ }^{11}$ Penggunaan tabir surya alami dapat diperoleh dari bahan alam, antara lain rimpang, buah, biji, bunga, batang, daun, akar, dan getah.Bagian tumbuhan tersebut mengandung senyawa fenolik yang berfungsi melindungi jaringan tanaman terhadap kerusakan akibat radiasi sinar matahari. Selain senyawa fenolik, flavanoid juga diduga dapat menangkal radikal induksi ultraviolet (UV), dan memberikan efek perlindungan terhadap radiasi UV dengan menyerap sinar UV. ${ }^{10}$

Jamur merupakah salah satu bahan alam yang penggunaannya sebagai obat sudah lama dilakukan. Salah satu jamur yang diperoleh dari alam dan dari budidaya komersil serta sangat popular adalah jamur kancing putih (Agaricus bisporus). Kandungan yang dimilikinya kaya akan protein, asam amino bebas, polifenol, polisakarida ergothionin, vitamin, asam linoleat yang tingi dan enzim aromatase yang berperan dalam mengkatalisis hormone seksyang terdapat pada manusia. Agaricus bisporus memiliki peran sebagai antioksidan, anti bakteri, anti inflamasi, anti tumor, dan sistem pertahanan tubuh. $^{3}$

Menurut Jeong et al. (2010), jamur kancing (Agaricus bisporus) memiliki kandungan yang kaya akan serat, polisakarida, antioksidan, vitamin dan polifenol sehingga dapat memberikan efek terhadap sel dari sistem imun, sel tumor.$^{3}$ Salah satu senyawa yang berperan sebagai antioksidan fotoprotektif terhadap sinar UV yang merugikan adalah senyawa fenolik. Efek antioksidan senyawa fenolik dikarenakan adanya sifat oksidasi dalam menetralisasi radikal bebas. Oleh karena itu senyawa antioksidan dapat dijadikan sebagai inhibitor untuk menghambat proses autooksidasi.

Dengan adanya kandungan senyawa antioksidan yang dimiliki oleh jamur kancing (Agaricus bisporus), maka diadakan penelitian mengenai nilai SPF yang dimiliki oleh jamur tersebut yang dilakukan secara in vitro dengan menggunakan metode spektrofotometri UV-Vis.

\section{METODE PENELITIAN}

Populasi dan Sampel

Populasi adalah jamur kancing (Agaricus bisporus) dan sampel adalah Ekstrak etanol jamur kancing (Agaricus bisporus)

\section{Metode Penelitian}

Metode yang digunakan yaitu secara eksperimental (True Expriment) laboratorium menggunakan metode Spektrofotometri UVVis secara In Vitro

\section{Alat dan Bahan yang digunakan}

Alat yang digunakan yaitu Corong, Cawan porselin, Labu ukur (pirex), gelas kimia (pirex), pipet volume, sendoktanduk, pipet tetes, spektrofotometer UV-Visible (Thermo), timbangan analitik (Ohaus), Sonikator (Krisbow). Bahan-bahan yang digunakan adalah Aquadest, jamur kancing (Agaricus bisporus)

\section{Prosedur Kerja}

\section{Penyiapan sampel penelitian}

\section{Pengambilan dan pengolahan sampel}

Sampel jamur kancing (Agaricus bisporus), diperoleh dari Bandung, Kemudian dibersihkan dari bebrapa kotoran yang menempel dengan menggunakan air yang mengalir dari kran dan dipotong-potong menjadi kecil kemudian dikeringkan dengan 
Penentuan nilai SPF (Sun Protecting Factor) ekstrak etanol jamur kancing (Agaricus bisporus) secara in vitro dengan metode spektrofotometri UV-VIS

cara diangin-anginkan tanpa sinar matahari \pm 1 minggu. Setelah kering sampel diserbukkan menggunakan blender.

\section{Ekstraksi Jamur Kancing (Agaricus bisporus)}

Sebanyak 300 gram serbuk jamur kancing (Agaricus bisporus) di masukkan kedalam wadah maserasi, ditambahkan pelarut etanol $96 \%$ hingga serbuk simplisia terendam, dan dibiarkan selama 3-4 hari, kemudian disaring. Setelah proses ekstraksi tersebut selesai,ampasnya kemudian dimaserasi kembali dengan cairan penyari etanol yang baru. Ekstrak kental yang telah dikumpulkan lalu diuapkan denganmenggunakan alat Rotary Vacuum Evaporator hingga diperoleh ekstrak etanol kental

Penyiapan larutan sampel ekstrak etanol jamur kancing (Agaricus bisporus)

Ekstrak etanol jamur kancing (Agaricus bisporus) yang telah diperoleh dibuat dalam konsentrasi $1 \% \mathrm{~b} / \mathrm{v} ; 2 \% \mathrm{~b} / \mathrm{v} ; 3 \%$ $\mathrm{b} / \mathrm{v} ; 4 \% \mathrm{~b} /$. Larutan sampel diultrasonikasi selama 12 menit kemudian disaring menggunakan kertas saring kedalam gelas kimia lalu di masukkan ke dalam labu ukur dan dicukupkan hingga $100 \mathrm{ml}$ dan di homogenkan. ${ }^{8}$

\section{Pengukuran absorban}

Masing-masing larutan Ekstrak etanol jamur kancing (Agaricus bisporus) yang dibuat dalam konsentrasi $1 \%, 2 \%, 3 \%, 4 \%$ diukur absorbannya pada panjang gelombang 290$320 \mathrm{~nm}$ dengan interval panjang gelombang 5 $\mathrm{nm}$ menggunakan spektrofotometer UV-Vis. Dalam pengukuran digunakan aquadest sebagai blanko. Nilai SPF dihitung berdasarkan data absorbansi sampel dengan menggunakan persamaan Mansur. ${ }^{6}$

Serapan diukur pada panjang gelombang 290, 295, 300, 305, 310, 315 dan $320 \mathrm{~nm}$. Nilai serapan yang diperoleh dikalikan dengan nilai EE $x$ I untuk masing- masing panjang gelombang yang terdapat pada tabel 1. Hasil perkalianserapan dengan EE $x \mathrm{I}$ dijumlahkan. Hasil penjumlahan dikalikan dengan faktor koreksi yang nilainya 10 untuk mendapatkan nilai SPF sediaan. Nilai EE $x$ I adalah suatu konstanta. Nilainya dari panjang gelombang 290-320 nm dan setiap selisih 5 $\mathrm{nm}$ telah ditentukan oleh (Sayre et al., 1979) seperti terlihat pada tabel berikut: ${ }^{15}$

Tabel 1.Nilai EE $x$ I pada panjang gelombang 290-320 nm.

\begin{tabular}{cc}
\hline Panjang gelombang $(\boldsymbol{\lambda} \mathbf{n m})$ & EE $\boldsymbol{x} \mathbf{~}$ \\
\hline 290 & 0,0150 \\
295 & 0,0817 \\
300 & 0,2874 \\
305 & 0,3278 \\
310 & 0,1864 \\
315 & 0,0839 \\
320 & 0,0180 \\
Total & 1 \\
\hline
\end{tabular}

\section{Analisis data}

Adapun analisis data nilai SPF Ekstrak etanol jamur kancing (Agaricus bisporus) yaitu nilaiserapan yang diperoleh dikalikan EE $x$ । untuk masing-masing interval. Nilai EE $x$ I tiap interval dapat dilihat pada tabel 1. Jumlah EE 
Penentuan nilai SPF (Sun Protecting Factor) ekstrak etanol jamur kancing (Agaricus bisporus) secara in vitro dengan metode spektrofotometri UV-VIS

x I yang diperoleh dikalikan dengan faktor

koreksi sehingga diperoleh nilai SPF dari sampel yang diuji. Perhitungan SPF: ${ }^{6}$

SPFspektrofotometer $=C F x \sum_{290}^{320}((\mathrm{EE}) x I(\lambda)) x(A b s(\lambda))$

$\begin{array}{ll}\text { Keterangan: } & \\ \text { CF } & =\text { Faktor koreksi } \\ \text { EE } & =\text { Spektrum efek eritema } \\ \text { I } & =\text { Spektrum intensitas matahari } \\ \text { Abs } & =\text { Absorbansi sampel }\end{array}$

HASIL DAN PEMBAHASAN

Hasil penelitian aktivitas perlindungan sinar UV ekstrak etanol jamur kancing (Agaricus bisporus) dengan menggunakan metode spektrofotometri UVVis menunjukkan bahwa nilai SPF ekstrak etanol jamur kancing (Agaricus bisporus) pada konsentrasi $1 \%$ sudah dapat memberikan aktivitas sebagai perlindungan sinar UV yang dihitung menggunakan persamaan Mansur yang dapat dilihat pada Tabel 2 :

Tabel 2. Nilai SPF ekstrak etanol jamur kancing (Agaricus bisporus) pada beberapa variasi konsentrasi.

\begin{tabular}{cccc}
\hline Sampel & $\begin{array}{c}\text { Konsentrasi Sampel ekstrak } \\
\text { etanol jamur kancing } \\
\text { (Agaricus bisporus) }\end{array}$ & $\begin{array}{c}\text { Nilai SPF Sampel ekstrak } \\
\text { etanol jamur kancing } \\
\text { (Agaricus bisporus) }\end{array}$ & $\begin{array}{c}\text { Kategori } \\
\text { SPF }\end{array}$ \\
\hline Ekstrak etanol & $1 \%$ & 17,672 & Sedang \\
jamur kancing & $2 \%$ & 28,643 & Sedang \\
(Agaricus bisporus) & $3 \%$ & 30,592 & Tinggi \\
\hline
\end{tabular}

\section{Keterangan:}

Klasifikasi Kekuatan SPF (Anderson, 2011).

a. SPF rendah (low) SPF $2-11$

b. SPF sedang (medium) SPF $12-29$

c. SPF tinggi (high) : SPF $30-50$

$\begin{array}{rlr}\text { Sun } & \text { Protection Factor } & \text { (SPF) } \\ \text { merupakan indikator universal yang }\end{array}$ menjelaskan tentang keefektifan dari suatu produk atau zat yang bersifat proteksi UV . Kulit adalah pertahanan pertama untuk tubuh secara pemaparan eksternal.8 Dalam upaya untuk melindungi kulit terhadap radiasi UV yang berbahaya dari matahari seringkali digunakan suatu senyawa tabir surya (sunscreen) untuk membantu mekanisme dalam pertahanan alami tubuh. ${ }^{8}$

Kulit merupakan organ tubuh terbesar yang memiliki fungsi utama sebagai pelindung antara tubuh bagian dalam dan bagian luar . Perlindungan kulit dari sinar UV dapat membantu mencegah efek penuaan dini dan kerusakan kulit lainnya seperti kanker kulit . ${ }^{1}$
Pada pemiihan produk perlindungan sinar UV, sebaiknya harus memerhatikan nilai SPF yang terdapat dalam setiap produk yang memiliki efek perlindungan sinar UV. Nilai tersebut menggambarkan kekuatan tabir surya dalam memberikan efek perlindungan kulit dari sengatan sinar UV. Jangka waktu kulit terlindungi oleh tabir surya sangat ditentukan oleh nilai SPF yang tertera pada produk tersebut.

Jika tanpa tabir surya kulit berubah merah dan terbakar dalam waktu 10 menit di bawah sinar matahari, maka pemilihan tabir surya didasarkan atas nilai SPF dikalikan dengan 10 menit yang menunjukkan lamanya daya tahan tabir surya dalam melindungi kulit. Misalnya, nilai SPF adalah 20, berarti tabir surya tersebut dapat melindungi kulit selama 
Penentuan nilai SPF (Sun Protecting Factor) ekstrak etanol jamur kancing (Agaricus bisporus) secara in vitro dengan metode spektrofotometri UV-VIS

$20 \times 10$ menit $=200$ menit dari sengatan sinar ultraviolet sebelum kulit menjadi terbakar dan merah.

Pada penelitian ini menggunakan jamur kancing (Agaricus bisporus) sebagai bahan untuk perlindungan sinar UV. Jamur merupakah salah satu bahan alam yang penggunaannya sebagai obat sudah lama dilakukan. Salah satu jamur yang diperoleh dari alam dan dari budidaya komersil serta sangat popular adalah jamur kancing putih (Agaricus bisporus). Kandungan yang dimilikinya kaya akan protein, asam amino bebas, polifenol, polisakarida ergothionin, vitamin, asam linoleat yang tingi dan enzim aromatase yang berperan dalam mengkatalisis hormone seksyang terdapat pada manusia. Agaricus bisporus memiliki peran sebagai antioksidan, anti bakteri, anti inflamasi, anti tumor, dan sistem pertahanan tubuh. $^{3}$

Spektrofotometri UV-Vis digunakan karena Spektrofotometri UV-Vis dapat menentukan sampel yang berupa larutan, yang akan diujikan secara in vitro dengan alat spektrofotometri UV- Vis untuk mengukur perbedaan absorbsi antara sampel oleh sinar UV pada panjang gelombang 290-320 nm. Kemudian hasil absorbansinya dicatat dan dihitung nilai SPFnya. Penentuan nilai SPF ini menggunakan persamaan Mansur.

Mekanisme SPF dapat menangkal radikal bebas dengan cara SPF menyerap dan menghambat pigmen melanin yang dapat terakumulasi sehingga dapat menghambat munculnya bintik-bintik hitam yang disebabkan oleh paparan sinar UV yang berlebih. Perlindungan sinar UV dapat menyerap sedikitnya $85 \%$ sinar matahari pada panjang gelombang 290-320nm untuk UV B tetapi dapat meneruskan sinar pada panjang gelombang lebih dari 320nm untuk UV A.

Berdasarkan hasil pengukuran dengan persamaan SPF ekstrak etanol jamur kancing (Agaricus bisporus) pada konsentrasi $1 \%, 2 \%$, memiliki kategori nilai SPF yang sedang, sedangkan pada konsentrasi 3\%, 4\% , memiliki kategori nilai SPF yang tinggi. Dengan nilai SPF secara berturut-turut 17,672; 28,643; 30,592 dan 31,325. Semakin tinggi konsentrasi yang digunakan maka nilai SPF yang diperoleh semakin baik. ${ }^{13}$ Adapun pembagian dari kelas SPF tersebut diklasifikasikan sebagai berikut, SPF rendah (low) SPF 2 - 11, SPF sedang (medium) SPF $12-29$ dan SPF tinggi (high) : SPF $30-50{ }^{1}$

\section{KESIMPULAN}

Dari hasil penelitian yang telah dilakukan dapat disimpulkan bahwa berdasarkan nilai SPF ekstrak etanol jamur kancing (Agaricus bisporus) memiliki aktivitas perlindungan sinar UV. Pada konsentrasi $1 \%$, $2 \%, 3 \%$ dan $4 \%$ telah memiliki aktivitas sebagai perlindungan sinar UV dengan nilai SPF secara berturut-turut 17,$672 ; 28,643$; 30,592 dan 31,325.

\section{DAFTAR PUSTAKA}

1. Anderson K. Sun Protection is easier than you think. USA: Ravalli County Extension Agent, Montana State University, 2011.pp5.

2. Droge W. Free Radicals in Physiological Control of Cell Function. Physiol Rev. 2002;82(1):47-95.

3. Falguera V, Miarnau O, Pagán J, Ibarz A. Inhibitory effect of melanins from Agaricus bisporus polyphenol oxidase and two different substrates on carboxypeptidases $A$ and $B$ activity. European Food Research and Technology. 2011;233(6):1075-1079.

4. Jeong $S C$, Jeong $Y T$, Yang BK, Islam $R$, Koyyalamudi SR, Pang G, Cho KY, Song $\mathrm{CH}$. White button mushroom (Agaricus bisporus) lowers blood glucose and 
Penentuan nilai SPF (Sun Protecting Factor) ekstrak etanol jamur kancing (Agaricus bisporus) secara in vitro dengan metode spektrofotometri UV-VIS

cholesterol levels in diabetic and hypercholesterolemic rats. Nutr Res. 2010;30(1):49-56.

5. Kioek MF. Formulasi Sediaan Hand Body Perasan Sari Buah Kiwi Hijau (Actinidia Deliciosa) Dalam Bentuk Milky Lotion (Skiripsi). Surabaya : Fakultas Farmasi, Universitas Katolik Widya Mandala, 2015.

6. Kochar SP and Rossell B. Detection estimation and evaluation of antioxidants in food system. In Hudson, B.J.F., (ed.). Food Antioxidants. London : Elsivier Applied Science, 1990.

7. Malsawmtluangi C, Nath DK, Jamatia I, Lianhimgthangi, Zarzoalina E, Pachua L. Determination of Sun Protection Factor (SPF) Number Of Some Aqueous Herbal Extracst. Journal of Applied Pharmaceutical Science. 2013;3(9):150151.

8. Mansur JS, Breder MNR, Mansur MCA, Azulay RD. Determination of sun protection factor for spectrophotometry. An. Bras. Dermatol. 1986;61:121-124.

9. Mbanga L, Mulenga M, Mpiana PT, Bokolo $K$, Mumbwa M, Mvingu K. Determination of Sun Protection Factor (SPF) of Some Body Creams and Lotions Marketed in Kinshasa by Ultraviolet Spectrophotometry. International Journal of Advanced Research in Chemical Science (IJARCS). 2014;1(8):7-13.

10. Nelson JL, Bernstein PS, Schmidt MC, Von Tress MS, Askew EW. Dietary modification and moderate antioxidant supplementation differentially affect serum carotenoids, antioxidant levels and markers of oxidative stress in older humans. J Nutr. 2003;133(10):3117-23.

11. Pradika Y. Uji Aktivitas Tabir Surya Ekstrak Batang Pisang Ambon (Musa paradisiaca Var. Sapientum) (Disertasi).Jogjakarta: Fakultas Sains dan Teknologi, Universitas Islam Negeri Sunan Kalijaga, 2016.

12. Susanti M, Dachriyanus, Putra DP. Aktivitas Perlindungan Sinar UVKulit Buah Garciniamangostana Linn secara in vitro. Pharmaco. 2012;13(2):61-64.

13. Tahir I. Arti Penting Kalibrasi pada Proses Pengukuran Analitik : Aplikasi pada Penggunaan $\mathrm{pH}$ meter dan Spektrofotometer UV-VIS. Universitas Gajah Mada. Yogyakarta, 2008 (September). Available at: https://www, researchgate, net/profile/lamal Tahir/publication/237627554 Arti Pentin g Kalibrasi Pada Proses Pengukuran A nalitik Aplikasi Pada Penggunaan $\mathrm{pHme}$ ter Dan Spektrofotometer UVVis/links/5472deb80cf216f8cfae8d2c.pdf.

14. Widyastuti, Fratama IR, Seprialdi A. Pengujian Aktivitas Antioksidan Dan Tabir Surya Ekstrak Etanol Kulit Buah Naga Super Merah. SCIENTIA. 2015;5(2):69-73.

15. Sayre RM, Agin PP, LeVee GJ, Marlowe E. A comparison of in vivo and in vitro testing of sunscreening formulas. Photochem Photobiol. 1979;29(3):559-66. 